\title{
Agribusiness-Based Corn Crop Development Strategy
}

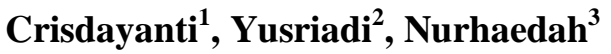 \\ ${ }^{123}$ JURUSAN AGRIBISNIS/FAKULTAS PERTANIAN, PETERNAKAN DAN PERIKANAN/ \\ UNIVERSITAS MUHAMMADIYAH PAREPARE
}

\author{
Email : \\ crisdayanti@gmail.com¹,yusri_adi@yahoo.co.id ${ }^{2}$,nurhaedah3372@gmail ${ }^{3}$ \\ (Received: Agu/2021; Reviewed: Sept/2021; Accepted: Sept/2021; Published: Okt/2021)
}

Ini adalah artikel dengan akses terbuka dibawah license CC BY-SA (2021 oleh penulis (https://creativecommons.org/licenses/by-nc/4.0/ ).

\begin{abstract}
This study aims to identify internal and external factors in the development of agribusiness-based corn plants and determine alternative strategies for agribusiness-based corn plant development in Pattondonsalu Village, Maiwa District, Enrekang Regency. The population in this study were 252 people. The method of random sampling for corn farmers was 21 people and the determination of key informants was deliberately taken (puposive) as 4 people because they were considered to know the most about the information presented, making it easier for the research process. The method used in this research is descriptive qualitative. This study uses IFAS, EFAS, and SWOT matrix data analysis. The research results are based on the analysis of the SWOT matrix, the appropriate alternative strategy is the Strategy-Oppottunities Strategy which is obtained from internal strength factors and external opportunities, namely Utilizing the availability of agricultural land to carry out corn cultivation activities so that the amount of corn demand can be met by utilizing technology and availability of facilities. superior and quality production by working with supporting institutions and input production retailers to meet the needs of farming and working with members of farmer groups to increase farmer motivation and absorption of labor from farmer groups so that maximum profits can be obtained.
\end{abstract}

Keywords: development strategy; corn; agribusiness

\section{ABSTRAK}

Penelitian ini bertujuan untuk mengidentifikasi faktor internal dan eksternal dalam pengembangan tanaman jagung berbasis agribisnis serta menentukan strategi alternatif terhadap pengembangan tanaman jagung berbasis agribisnis di Desa Pattondonsalu Kecamatan Maiwa Kabupaten Enrekang. Adapun jumlah populasi pada penelitian ini sebanyak 252 orang. Metode pengambilan sampel secara acak untuk petani jagung sebanyak 21 orang dan penentuan informan kunci (key informan) yang diambil secara sengaja (puposive) sebayak 4 orang karna dianggap paling tahu tentang informasi yang dihapkan sehingga memudahkan dalam proses penelitian. Metode yang digunakan dalam penelitian ini yaitu deskriptif kualitatif. Penelitian ini menggunakan analisis data IFAS, EFAS, dan matriks SWOT. Adapun hasil peneltian berdasarkan analisis dari matriks SWOT, strategi alternatif yang tepat yaitu Strategi Strenghts-Oppottunities yang diperoleh 


\begin{abstract}
dari faktor kekuatan internal dan peluang eksternal yaitu Memanfaatkan ketersediaan lahan usaha tani untuk melakukan kegiatan budidaya jagung sehingga jumlah permintaan jagung dapat terpenuhi dengan pemanfaatan teknologi dan ketersediaan sarana produksi yang unggul dan bekualitas dengan bekerja sama dengan lembaga pendukung dan pengecer saprodi untuk memenuhi kebutuhan usaha tani dan bekerja sama dengan anggota kelompok tani untuk meningkatkan motifasi petani dan penyerapan tenaga kerja yang berasal dari kelompok tani sehingga dapat diperoleh keuntungan maksimal.
\end{abstract}

Kata Kunci: strategi pengembangan; jagung; agribisni.

\title{
PENDAHULUAN
}

Tanaman jagung merupakan komoditas tanaman palawija yang diminta di pasar dunia dikarenakan pemanfaatannya yang cukup luas terutama untuk pangan atau konsumsi manusia, pakan dan bahan baku industri lainnya. Jagung juga merupakan komoditi tanaman pangan kedua yang terpenting setelah padi. Namun tanaman jagung pada umumnya seperti komoditas pangan lainnya karena diproduksi oleh petani dengan skala kecil sehingga dibutuhkan kebijakan strategis untuk meningkatkan jumlah produktifitas dan pendapatan karna dengan kebijakan bussiness as usual upaya peningkatan jumlah produksi tidak dapat mengimbangi jumlah peningkatan permintaan. Hal tersebut juga diungkap oleh (Nurdin et al., 2021) bahwa pertanian masih dalam proses dan pelaksanaan mekanisasi untuk mengadopsi teknologi modern yang ramah lingkungan guna membantu para petani dalam usaha tani.

Kabupaten Enrekang merupakan penyumbang hasil produksi jagung di Sulawesi Selatan. Meskipun berada di daerah pegunungan dan perbukitan, petani di Kabupaten Enrekang mampu menghasilkan hasil panen yang melimpah. Kecamatan Maiwa merupakan daerah pertanian yang cukup luas di Kabupaten Enrekang yang merupakan sentra pertanian tanaman jagung. Salah satu daerah penghasil jagung yang cukup besar yaitu Desa Pattondonsalu.

Desa Pattondonsalu merupakan salah satu daerah pengembangan tanaman jagung, Namun ada banyak permasalahan yang dihadapi petani salah satunya belum mampu memaksimalkan pendapatan mereka dikarnakan belum mengetahui bagaimana strategi yang tepat untuk meningkatkan hasil usaha tani mereka. Sedangkan peluang yang dimiliki petani di desa Pattondonsalu cukup besar dikarenakan terdapat beberapa industri pakan ternak dan peternakan ayam yang cukup banyak. Maka dengan perkembangan usaha industri dan peternakan ayam maka potensi Desa Pattondonsalu untuk produksi jagung pipil kering sebagai pemasok industri pakan ternak yang membutuhkan jagung sebagai bahan baku jagung sehingga pengembangan agribisnis jagung memiliki prospek yang besar jika dikelolah dengan benar.

Berdasarkan penjelasan yang di atas dan melihat potensi yang dimiliki oleh Desa Pattondonsalu, maka peneliti berinisiatif melakukan penelitian berkaitan dengan Strategi Pengembangan Tanaman Jagung berbasis Agribisnis di Desa Pattondonsalu Kecamatan Maiwa Kabupaten Enrekang.

Penelitian ini bertujuan untuk Mengidentifikasi faktor internal dan eksternal dalam pengembangan tanaman jagung dan Menentukan strategi alternatif yang tepat dalam pengembangan tanaman jagung berbasis agribisnis di desa Pattondonsalu Kecamatan Maiwa 
Kabupaten Enrekang yang nantinya digunakan untuk mengembangkan usaha tani jagung dilokasi penelitian sehingga petani dapat memperoleh hasil yang maksimal.

\section{METODE}

Jenis penelitian yang digunakan adalah penelitian deskriptif kualitatif penelitiain ini bertujuan untuk menggambarkan keadaan atau kondisi sebenarnya yang ada di lapangan terutama dalam kaitannya dengan penelitian yang di ambil. Menurut (Sugiyono 2017:59) penelitian kualitatif di gunakan untuk menentukan, mencari, mengumpulkan, mengolah dan menganalisis data hasil penelitian tersebut.

\section{Lokasi Penelitian} Enrekang.

Penelitian ini dilaksanakan di Desa Pattondonsalu Kecamatan Maiwa Kabupaten

\section{Sumber Data}

Sumber data yang diperoleh dalam penelitian ini adalah berasal dari responden yang telah diwawancarai. Adapun informan yang di wawancarai dalam penelitian ini yaitu :

a. Informan kunci adalah informan yang mengetahui secara mendalam permasalan yang akan diteliti. Dalam hal ini yang menjadi informan kunci adalah Penyuluh pertanian, ketua kelompok tani dan petani jagung.

b. Informan pendukung yaitu informan yang ditentukan dengan dasar pertimbangan memiliki pengetahuan dan sering berhubungan baik secara formal maupun informal dengan para informan kunci. Dalam penelitian ini informan pendukung yaitu instansi pemerintah dalam hal ini kordinator BPP Kecamatan Maiwa.

\section{Teknik Pengumpulan Data}

Teknik pengumpulan data yang digunakan dalam penelitian ini terdiri dari dua jenis, yaitu data primer dan data sekunder. Data primer adalah data yang diperoleh langsung dari lapangan, baik melalui tahap observasi maupun tahap wawancara dengan menyusun daftar pertanyaan. Data sekunder, yaitu data pendukung yang diperoleh dari berbagai sumber atau instansi sehingga memudahkan memperoleh hasil yang dibutuhkan oleh peneliti.

\section{Analisis Data}

Data yang diperoleh dalam penelitian ini kemudian diidentifikasi dengan strategi IFAS (internal factor analysis summary) dan EFAS (external factor analysis summary), sedangkan strategi matriks I-E (internal-eksternal) dan pemilihan alternatif strategi yang sesuai dengan menggunakan matriks SWOT (streengths, weaknesses, opppotunities, threats) Matriks I - E (Internal-Eksternal) adalah salah satu paramenter yang meliputi parameter kekuatan internal dan pengaruh eksternal perusahaan yang masing-masing akan mengidentifikasi kedalam elemen eksternal dan internal melalui matriks IFAS dan EFAS. Menurut (Rangkuti, 2017:51) matrik I - E (Intrnal - External) pemetaan skor matiks EFAS dan IFAS yang telah dihasilkan dari tahap input (input stage), digunakan untuk menganalisis masalah selanjutnya. Hasil pengolahan data disajikan dalam bentuk tabel, foto dan deskripsi.

\section{HASIL DAN PEMBAHASAN}

\section{Hasil}

\section{Karakteristik Responden}


Crisdayanti, Yusriadi, Nurhaedah, 2021, Strategi Pengembangan Tanaman Jagung Berbasis Agribisnis

Karakteristik responden merupakan gambaran secara umum tengtang keadaan dan dalat belakang responden. Responden yang digunakan dalam penelitian ini diklarisifikasikan berdasarkan jenis kelamin, usia, pendidikan dan pekerjaan responden. Berikut adalah data karateristik responden sebagai berikut :

Tabel 1. Responden berdasarkan jenis kelamin

\begin{tabular}{llcc}
\hline No & Jenis kelamin & $\begin{array}{c}\text { Jumlah responden } \\
\text { (orang) }\end{array}$ & Persentase (\%) \\
\hline 1 & Laki-laki & 21 & 84 \\
2 & Perempuan & 4 & 16 \\
\hline & Total & $\mathbf{2 5}$ & $\mathbf{1 0 0}$
\end{tabular}

Sumber : Data Primer Setelah Diolah, 2020

Berdasarkan tabel 1 diatas menunjukkan bahwa jumlah responden jenis kelamin lakilaki sebanyak 21 orang atau $84 \%$ dari semua reponden. Hal ini disebabkan karena petani lakilaki lebih produktif dibanding perempuan sehingga jumlah laki-laki yang melakukan usaha tani jagung lebih banyak.

Tabel 2. Deskripsi Responden Berdasakan Umur

\begin{tabular}{cccc}
\hline No & Umur (Tahun) & $\begin{array}{c}\text { Jumlah responden } \\
\text { (orang) }\end{array}$ & $\begin{array}{c}\text { Persentase } \\
(\boldsymbol{\%})\end{array}$ \\
\hline 1 & $21-30$ & 4 & 16 \\
2 & $31-40$ & 2 & 8 \\
3 & $41-50$ & 9 & 36 \\
4 & $51-60$ & 10 & 40 \\
\hline & Total & $\mathbf{2 5}$ & $\mathbf{1 0 0}$ \\
\hline
\end{tabular}

Sumber : Data Primer Setelah Diolah, 2020

Umur responden yang dikelompokkan seperti pada tabel 2 yaitu Berdasakan jumlah terbesar yaitu umur 50 tahun - 60 tahun masih tergolong usia produktif, walaupun pada kenyataannya petani jagung yang mempunyai umur tua dan lahan yang cukup luas namun semangat dan kemauan mereka untuk tetap berusahatani masih tinggi karna hasil dari usaha tani tersebut digunakan untuk memenuhi kebutuhan kelurganya.

Tabel 3. Deskripsi Responden Berdasakan Pendidikan

\begin{tabular}{lccc}
\hline No & Umur (Tahun) & Jumlah responden & Persentase (\%) \\
\hline 1 & SD & 7 & 28 \\
2 & SMP & 8 & 32 \\
3 & SMK/SMA & 6 & 24 \\
4 & SARJANA & 4 & 16 \\
\hline & Total & $\mathbf{2 5}$ & $\mathbf{1 0 0}$
\end{tabular}

Sumber : Data primer setelah diolah, 2020

Data pada tabel 3 menunjukkan tingkat pendidikan rata-rata responden tertinggi yaitu pendidikan SMP sebanyak 8 orang atau 32\%. Jumlah petani dengan pendidikan SMP lebih banyak dikarnakan faktor ekonomi sehingga tidak bisa melanjutkan sekolah kejenjang berikutnya. Pendidikan rendah bukan alasan untuk mereka tidak melakukan usaha tani karna 
ketersediaan lahan pertanian dan jumlah permintaan jagung yang tinggi menyebabkan banyak petani memilih menjadi petani jagung untuk membantu perekonomiannya.

\section{Karakteristik Agribisnis Petani Jagung}

Pengembangan tanaman jagung berbasisi agribisnis di Desa Pattondonsalu Kecamatan Maiwa Kabupaten Enrekang dari hasil observasi lokasi dan hasil wawancara ditemukan fakta tentang kondisi agribisnis petani.

\section{a. Subsistem Input dan Sarana Produksi}

Petani di desa pattondonsalu memiliki potensi lahan yang cukup dalam pengembangan tanaman jagung. rata-rata luas lahan yang dikelokah yaitu 2-4 Ha. Petani di Desa Pattondonsalu memiliki keunggulan dalam hal penyediaan sarana produksi yaitu benih dan pupuk subsidi yang berasal dari pengecer sarana produksi yang tersedia, namun tak jarang petani membeli benih, pupuk dan pestisida dari pedagang luar karna belum mencukupi kebutuhan petani. Penyediaan sarana produksi lain seperti penggunaan teknologi farm traktor, mesin plinter, handsprayer dan cangkul merupakan bantuan dari pemerintah dan juga ada yang dibeli sendiri oleh petani. Dengan adanya teknologi ini akan memudahkan petani dalam proses budidaya nantinya.

Sejalan dengan penelitian (Akbar, 2013) mengemukakan bahwa penggunaan factorfaktor produksi seperti luas lahan, benih, pupuk dan tenaga kerja berpengaruh nyata terhadap peningkatan hasil produksi jagung

\section{b. Subsistem Usahatani atau Proses Produksi}

Petani di lokasi penelitian mulai menanam pada awal musim hujan karna tersedianya air untuk pertumbuhan tanaman jagung yang cukup. Sebelum menanam petani terlebih dahulu mengolah lahan dengan cara dibajak dengan menggunakan farm traktor tapi ada juga yang hanya melakukan sanitasi lahan menggunakan penyemprotan herbisida lalu langsung menanam. Umumnya petani menggunakan tajak atau kayu modifikasi yg ujungnya runcing tapi ada juga yang menggunakan alat planter untuk menanam. Penanaman dimulai dengan pembuatan lobang tanam berkisar 2-5 cm dengan jarak tanam $20 \mathrm{~cm}$ jika menggunakan tajak. Jika menggunakan alat planter petani hanya perlu mendorong mesin dan 1 orang dibelakang untuk mengawasi jagung apakah sudah tertutup atau tidak.

Proses pemeliharaan dilakukan dengan penyulaman tanaman yang mati, penjarangan untuk jagung yang tumbuh dalam jumlah banyak dalam 1 lubang, pembumbunan agar tanah disekitar jagung menjadi gembur dan pemberian pupuk kimia serta penyemprotan pestisida. Proses pemupukan dilakukan 1 kali dalam 1 kali musim tanam. Penggunaan pupuk kimia seperti Ponska dan Urea rata-rata menggunakan 10 sak dengan perbandingan 1:1 untuk luas lahan1 Ha.

Pemanenan dilakukan pada kisaran umur 90 hari. Jika pohon tanaman jagung mulai berubah menjadi coklat dan mengering itu tandanya jagung sudah siap dipanen.

c. Subsistem Pengolahan Pasca Panen

Pengolahan pasca panen yang dilakukan oleh petani jagung yaitu proses pemipilan dengan menggunakan mesin perontok jagung lalu dijemur pada tempat yang datar dan kering seperti pada tembok khusus pengering maupun menggunakan tenda plastik sampai kering agar harga jualnya lebih mahal dibanding dengan dijual dalam keadaan basah. Berdasarkan hasil penelitian terdapat beberapa industri pengolahan jagung yang dimiliki oleh peternak ayam kemudian diolah menjadi pakan ternak ayam. Sejalan dengan penetian (Darwis, 2019) menyatakan bahwa proses pasca panen jagung jagung terdiri atas serangkaian kegiatan setelah 
panen yang dimulai dari pemipilan, pengeringan, pengemasan dan penyimpanan sebelum dijual ke pedagang pengepul.

\section{d. Subsistem Pemasaran}

Hasil produksi yang diperoleh petani di Desa Pattondonsalu langsung dijual ke pengepul industri pakan ternak ada juga yang langsung ke pedagang. Berdasarkan hasil penelitian harga biji jagung kering yang dijual petani berkisar Rp2.500-Rp3.800/Kg. Fluktuasi harga yang dialami petani terkadang hanya memberikan sedikit keuntungan dikarnakan banyaknya pesaing produk yang sama dari luar daerah. Kerjasama yang dilakukan petani dengan pedagang pengumpul dan industri pakan ternak membuat petani tidak perlu memasarkan produknya dengan susah payah dan jauh karna akan langsung dijemput oleh pedagang.

Namun menurut (Sari et al., 2012) Strategi pemasaran di pedagang besar belum dapat meningkatkan efisiensi pemasaran karena homogennya produk yang dijual yaitu jagung kering pipilan. Penentuan harga jual jagung pipilan ini bergantung pada kualitas dan biaya produksi. Maka dari itu petani harus memperbaiki proses budidaya sampai dengan pasca panen untuk memperbaiki kualitas hasil produksi.

\section{e. Subsistem Penunjang atau Kelembagaan}

Sarana penunjang yang dimaksud adalah sarana tataniaga, lembaga keuangan atau koperasi, transportasi, kelompok tani dan penyuluh. Kelembagaan ditingkat petani dilokasi penelitian seperti kelompok tani dan penyuluh sudah baik karna dengan adanya kelompok tani dan penyuluh memudahkan petani dan penyuluh bertukar informasi mengenai jagung. Selain itu terdapat pengecer sarana produksi seperti bibit, pupuk dan pestisida sehingga memudahkan petani dalam kegiatan usaha tani tanpa harus keluar daerah untuk membeli. Sarana trasportasi seperti mobil pengangkut dan juga penggunaan motor taksi juga digunakan petani untuk mengangkut hasil panen kelokasi yang dituju.

\section{Identifikasi IFAS dan EFAS}

Model analisis SWOT untuk menetapkan strategi strategi dengan membandingkan faktor internal yang berupa kekuatan dan kelemahan dengan faktor eksternal peluang dan ancaman. Faktor internal dan eksternal yang ditetapkan akan dimasukkan kedalam tabel Internal Factors Analysis Summary (IFAS) dan External Factors Analysis Summary (EFAS). Hasil dari analisis tersebut akan dilihat apakah strategi-strategi yang dilakukan dapat mengetahui meningkatkan kekuatan dan peluang serta mengatasi kelemahan dan ancaman yang dimiliki.

Tabel 4. Internal Factors Analysis Summary (IFAS)

\begin{tabular}{lccc}
\multicolumn{1}{c}{ Faktor Internal } & Bobot & Rating & Skor \\
\hline Kekuatan (Strengths) & & & \\
A. Tersedianya Lahan Usaha Tani & 0,11 & 2 & 0,22 \\
B. Penggunaan Bibit Unggul & 0,08 & 3 & 0,24 \\
C. Ketersediaan Sarana Produksi & 0,10 & 3 & $\mathbf{0 , 3 0}$ \\
D. Bergabung Dalam Kelompok Tani & 0,10 & 3 & $\mathbf{0 , 3 0}$ \\
E. Tingginya Motifasi Petani & 0,10 & 4 & $\mathbf{0 , 4 0}$ \\
$\quad$ Jumlah & & & $\mathbf{1 , 4 6}$ \\
Kelemahan (Weaknesess) & 0,11 & 2 & $\mathbf{0 , 2 2}$ \\
F. Manajemen Usaha Tani & 0,08 & 3 & 0,24 \\
G. Sumber Daya Manusia (Sdm) & 0,10 & 3 & 0,3 \\
H. Ketergantungan Petani Ke Pedagang & & & \\
\hline
\end{tabular}




\begin{tabular}{llll}
\hline I. Belum menerapkan teknik bubidya & 0,11 & 1 & $\mathbf{0 , 1 1}$ \\
$\quad \begin{array}{l}\text { yang dianjurkan } \\
\text { J. Terbatasnya Modal }\end{array}$ & 0,11 & 4 & 0,44 \\
$\quad$ Jumlah & & & 1,31 \\
\hline Total & $\mathbf{1 , 0 0}$ & & $\mathbf{2 , 7 7}$ \\
\hline
\end{tabular}

Sumber : Data Primer Setelah Diolah, 2020

Tabel 4 menunjukkan bahwa nilai skor terbesar faktor kekuatan yaitu 0,40 yaitu tingginya motifasi petani dan 0,30 yaitu penyediaan sarana produksi serta adanya kelompok tani yaitu 0,30. Adapun kelemahan utama dalam pengembangan tanaman jagung yaitu belum menerapkan teknik budidaya yang dianjurkan dengan nilai 0,11 dan manajemen usaha tani rendah dengan nilai 0,22 dari jumlah keseluruhan skor 2,77.

Tabel 5. Eksternal Strategic Factors Analysis Summary (EFAS)

\begin{tabular}{lccc}
\hline Faktor Eksternal & Bobot & Rating & Skor \\
\hline Peluang (Opportunities) & & & \\
A. Tingginya Permintaan Jagung & 0,12 & 3 & $\mathbf{0 , 3 6}$ \\
B. Pemanfaatan Teknologi Pertanian & 0,10 & 4 & $\mathbf{0 , 4 0}$ \\
C. Adanya Lembaga Pendukung & 0,08 & 3 & 0,24 \\
D. Penyerapan Tenaga Kerja & 0,10 & 2 & 0,20 \\
E. Adanya Pengecer Saprodi & 0,10 & 2 & 0,20 \\
$\quad$ Jumlah & & & $\mathbf{1 , 4 0}$ \\
Ancaman (Threats) & 0,11 & 4 & 0,44 \\
F. Serangan Hama dan Penyakit & 0,09 & 2 & 0,18 \\
G. Persaingan Produk sejenis & 0,11 & 1 & $\mathbf{0 , 1 1}$ \\
H. Perubahan Cuaca & 0,08 & 1 & $\mathbf{0 , 0 8}$ \\
I. Harga Jagung Fluktuasi & 0,11 & 3 & 0,33 \\
J. Produk Mudah Rusak & & & $\mathbf{1 , 1 4}$ \\
$\quad$ Jumlah & $\mathbf{1 . 0 0}$ & & $\mathbf{2 , 5 4}$ \\
\hline Total & &
\end{tabular}

Tabel 5 menunjukkan bahwa peluang utama dalam pengembangan tanaman jagung yaitu penggunaan teknologi pertanian 0,40 dan permintaan jagung yang tinggi dengan skor nilai 0,36 dari total skor 2,54. Ancaman utama yang diperoleh berdasarkan skor nilai 0,08 harga jagung yang fluktuasi dan perubahan cuaca yaitu 0,11 dari total nilai keseluruhan 2,54.

Berdasarkan hasil analisis dari tabel IFAS dan EFAS yaitu pada tabel IFAS skor ratarata sebesar 2,77 yang mengambarkan bahwa tanaman jagung berada dalam kondisi internal yang sedang, sedangkan pada tabel EFAS skor rata-rata sebesar 2,54 menggambarkan bahwa respon petani dalam memanfaatkan peluang untuk mengatasi ancaman tergolong sedang pula. Total nilai yang dibobot pada tabel IFAS dan EFAS akan disusun pada matriks InternalEksternal (IE), sehingga dapat diketahui posisi usahatani tanaman jagung, kemudian akan dirumuskan strategi yang sesuai dengan posisi usahatani tanaman jagung di matriks I-E. Berikut gambar matriks I-E untuk mengetahui posisi usahatani tanaman jagung di Desa Pattondonsalu. 


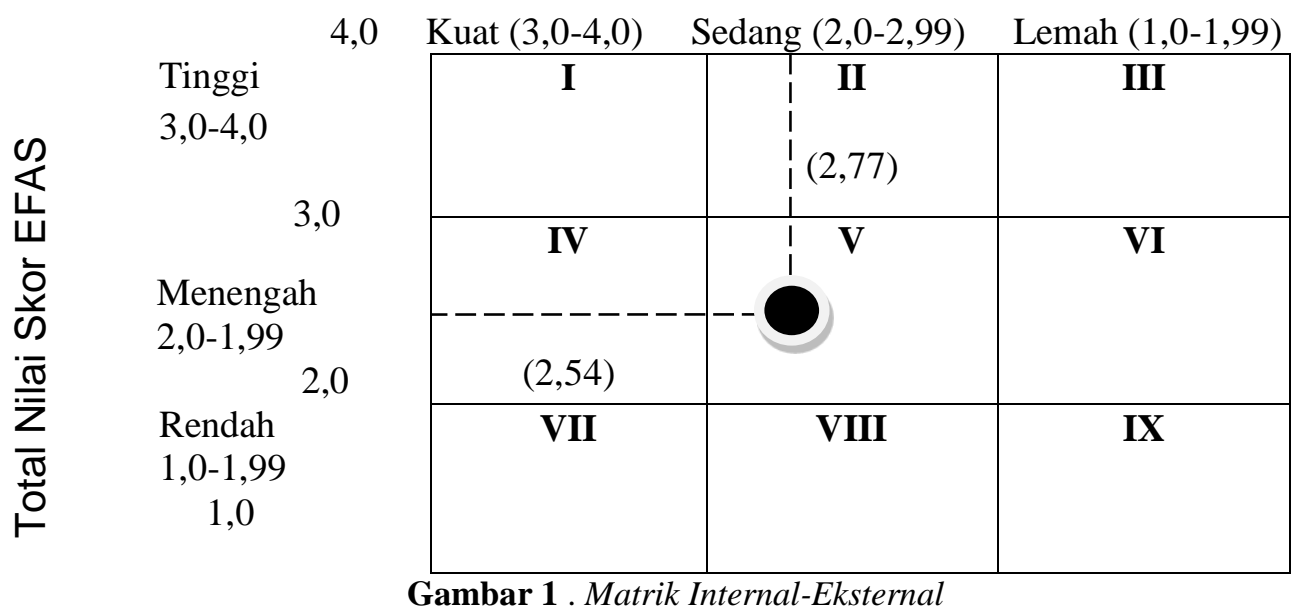

Total skor yang telah dihitung dengan menggunakan matriks IFAS dan EFAS pada gambar 1 menunjukkan bahwa posisi usaha tani tanaman jagung yang ada di Desa Pattondonsalu berada pada kotak sel V yaitu menggambarkan strategi jaga dan pertahankan. Hal ini mendakan usaha tani yang dijalankan sudah baik namun tetap melakukan inovasi agar tidak terjadi penurunan pada usaha yang dijalankan.

Berdasarkan hasil perhitungan tabel diatas menunjukkan bahwa di dalam perhitungan strateginya memerlukan penegasan adanya posisi salib sumbu yaitu antara kekuatan dan kelemahan, maupun peluang dan ancaman seperti yang digambarkan pada garis-garis positif negatif. Hal ini menggambarkan total skor kekuatan tetap 1,46 dan total skor kelemahan 1,31. Sedangkan total skor peluang 1,40 dan total skor ancaman 1,14. Analisis tersebut menggambarkan bahwa faktor kekuatan lebih besar dari kelemahan dan berpengaruh pada faktor peluang yang lebih besar dari ancaman.

Koordinatnya dapat diketahui dengan cara hasil Koordinat analisis Internal yang diperoleh dari pengurangan skor total kekuatan dan skor total kelemahan yaitu 1,46-1,31 = 0,15 . Sedangkan untuk memperoleh koordinat eksternal skor total peluang - skor total ancaman yaitu $1,40-1,14=0,26$.

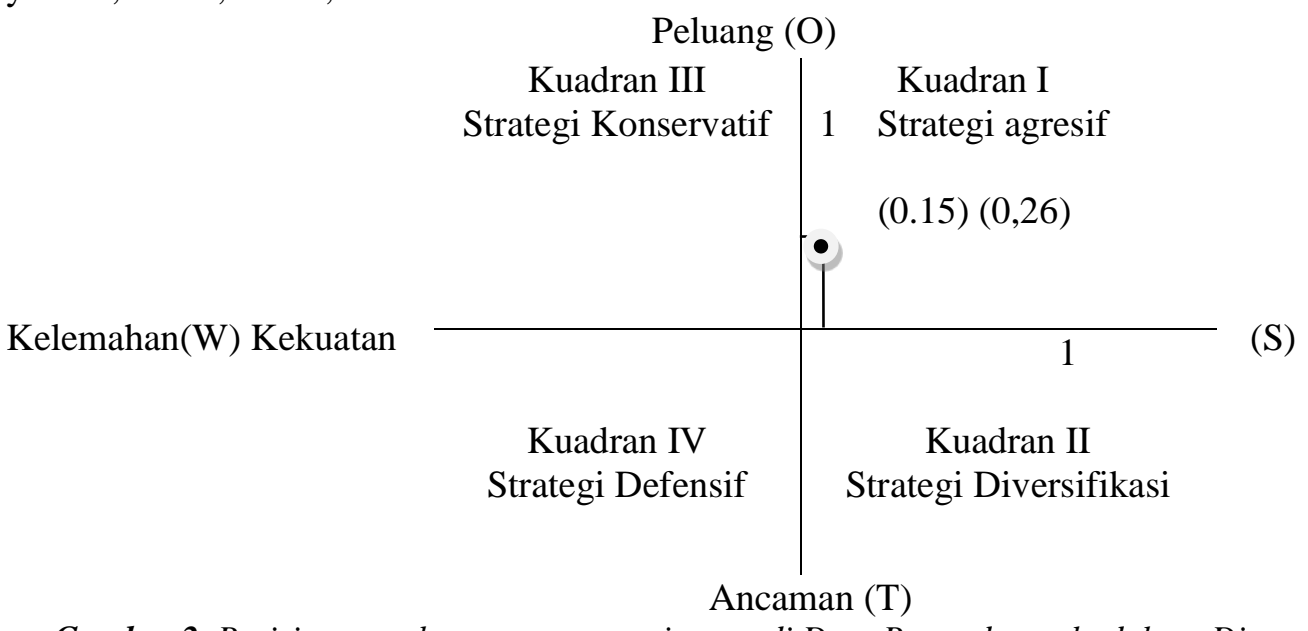

Gambar 2. Posisi pengembangan tanaman jagung di Desa Pattondsonsalu dalam Diagram SWOT 
Melihat gambar di atas posisi pengembangan tanaman jagung di Desa Pattondonsalu berada pada kuadran I yang berarti posisi ini menandakan sebuah organisasi yang kuat dan berpeluang. Rekomendasi strategi yang diberikan adalah agresif, artinya organisasi dalam kondisi prima dan mantap sehingga sangat memungkinkan untuk terus melakukan ekspansi, memperbesar pertumbuhan dan meraih kemajuan secara maksimal (Rangkuti, 2017).

Rumus matriks SWOT selanjutnya adalah membuat strategi yang dapat disarankan atau direkomendasikan, yaitu menyusun matik SO, ST, WO, WT. Strategi ini diperoleh dari perhitungan pada tabel IFAS dan EFAS kemudian dilakukan penjumlahan seperti yang telihat pada tabel 6.

Tabel 6. Penjumlahan skor Kekuatan (S), Kelemahan (W), Peluang (O) dan Ancaman (T).

\begin{tabular}{|l|l|}
\hline SO & WO \\
Skor $(\mathrm{S})+$ Skor $(\mathrm{O})$ & Skor $(\mathrm{W})+$ Skor $(\mathrm{O})$ \\
$1,46+1,40=2,86$ & $1,31+1,40=2,71$ \\
\hline ST & WT \\
Skor $(\mathrm{S})+$ Skor $(\mathrm{T})$ & Skor $(\mathrm{W})+$ Skor $(\mathrm{T})$ \\
$1,46+1,14=2,60$ & $1,31+1,14=2,45$ \\
\hline
\end{tabular}

Sumber : Data Primer Setelah Diolah, 2020

Pada tabel 6 diatas menunjukkan bahwa nilai penjumlahan tertinggi adalah penjumlahan skor kekuatan (S) dan peluang (O) selanjutnya disebut strategi SO, yaitu sebesar 2,86 dan terrendah diperoleh dari penjumlahan skor kelemahan (W) dan ancaman (T) sebesar 2,45.

\section{Pembahasan}

\section{Perumusan Strategi Dengan Matriks I-E dan Analisis SWOT}

Tingginya motifasi petani dan penyediaan sarana produksi serta adanya kelompok tani menjadi faktor utama dalam pengembangan tanaman jagung. Dengan motifasi dan usaha petani yang kuat akan membuat petani mampu mencapai tujuan usaha tani jagung yang didukung oleh ketersediaan sarana produksi seperti benih, pupuk, pestisida dan pemanfaatan kelompok tani sehingga kegiatan usaha tani jagung dapat dilakukan dengan mudah. Adapun kekuatan dari agribisnis jagung yang disimpulkan menurut (Jufri et al 2016) di antaranya: potensi alam yang mendukung, tersedianya sarana produksi, ketersediaan tenaga kerja dalam memproduksi jagung dapat meningkatkan hasil produksi jagung. Sedangkan Lemahnya menejemen usaha tani dan teknik budidaya petani yang salah membuat usaha tani jagung menjadi melemah sehingga produktifitas hasil panen juga menurun. Menurut (Lestari, 2015) modal merupakan hal utama yang perlu disediakan dalam melakukan usaha tani, jika kebutuhan sarana produksi terpenuhi dan melakukan kegiatan budidaya yang sesusai yang dianjurkan maka produktifitas bisa meningkat.

Penggunakan teknologi dapat memudahkan petani dalam melakukan usahatani jagung dan permintaan jagung yang tinggi membuat petani terus melakukan kegiatan usaha tani jagung untuk memenuhi kebutuhan konsumen. Menurut (Hasan et al., 2020) peningkatan produksi secara ekstensifikasi dilakukan melalui perluasan areal tanaman usahatani jagung baik pada lahan yang belum diolah (lahan tidur) maupun lahan bukaan baru. Sedangkan Harga jagung yang fluktuasi menjadi ancaman karna pengetahuan petani masih rendah dalam hal pemasaran jagung sehingga belum memiliki solusi jika fluktuasi harga terjadi. Maka petani hanya mengikut kepada pedagang yang membeli jagung dengan harga yang di tetapkan oleh pedagang. Perubahan cuaca yang tidak menentu menjadi ancaman utama karna jika curah hujan tinggi dapat mengakibatkan tanaman menjadi mati karna kelebihan air, begitupun dengan musim 
kemarau tanaman akan mati jika tidak terkena air, jadi petani harus pandai dalam menentukan jadwal penanaman dan pemanenan.

Merujuk pada hasil dari matriks I-E (Internal-eksternal) Hal ini menunjukkan bahwa kondisi Pengembangan tanaman jagung di Desa Pattondonsalu kuat. Berdasarkan posisi tersebut maka pihak yang terkait harus menerapkan Strategi Agresif yaitu lebih menggunakan kekuatan utamannya yaitu tingginya motifasi petani untuk memaksimalkan peluang dengan pemanfatan teknologi pertanian sehingga kegiatan usaha tani jagung dapat dilakukan dengan mudah karena adanya teknologi yang tesedia sehingga ada inovasi yang diperoleh oleh petani untuk terus melakukan usaha tani jagung.

Adapun alternatif strategi pengembangan tanaman jagung berbasis agribisnis di Desa Pattondonsalu Kecamatan Maiwa Kabupaten Enrekang diperoleh dari berbagai kombinasi antara faktor internal dan eskternal Berdasarkan hasil analisis matriks SWOT yaitu :

\section{a. Strategi Strenghts-Oppottunities (SO)}

Strategi Strenghts-Oppottunities yang diperoleh dari faktor kekuatan internal dan peluang eksternal yaitu Memanfaatkan ketersediaan lahan usaha tani untuk melakukan kegiatan budidaya jagung sehingga jumlah permintaan jagung dapat terpenuhi dengan pemanfaatan teknologi dan ketersediaan sarana produksi yang unggul ldan bekualitas dengan bekerja sama dengan lembaga pendukung dan pengecer saprodi untuk memenuhi kebutuhan usaha tani dan bekerja sama dengan anggota kelompok tani untuk meningkatkan motifasi petani dan penyerapan tenaga kerja yang berasal dari kelompok tani.

\section{b. Strategi Wesknesess-Opottunities (WO)}

Strategi Wesknesess-Opottunities yang diperoleh dari faktor kelemahan internal dan ancaman eksternal yaitu Memperbaiki pola manajemen petani dan kualitas sumber daya manusia (SDM) terutama dalam hal tenaga kerja, pemanfaatan teknologi pertanian dan menggunakan teknik budidaya yang sesuai anjuran sehingga produktifitas bisa meningkat dan memenuhi jumlah permintaan jagung yang tinggi. Serta memperbanyak kerja sama dengan lembaga pendukung seperti, lembaga pemasaran dan distribusi dalam penentuan harga dan penjualan jagung, serta memanfaatkan pengecer saprodi sebagai wadah untuk simpan pinjam kebutuhan usaha tani yang kekurangan modal.

\section{c. Strategi Strenghts-Threats (ST)}

Strategi Strenghts-Threats yang diperoleh dari faktor kekuatan internal dan ancaman eksternal yaitu menggunakan sarana produksi yang unggul dan berkualiutas pada lahan usaha tani yang tersedia untuk meningkatkan produktifitas hasil panen dan kualitas produk sehingga bisa bersaing dengan produk dari luar serta memanfaatkan kelompok tani sebagai wadah dalam bekerja sama termasuk dalam hal mengatasi masalah jika terjadi serangan hama dan penyakit, perubahan cuaca dan fluktuasi harga.

Menurut (Anwar \& Muhammad, 2019) petani memiliki pengalaman usaha tani yang cukup lama sehingga bermanfaat dalam menganggulangi hama dan penyakit jagung, keberadaan kelompok tani dan gapoktan sebagai wadah komunikasi dan pembinaan bagi petani lebih memudahkan, membuka akses dan peluang kerjasama dengan lemabaga-lembaga pendukung yang mampu menampung hasil produksi dan menjaga kestabilan harga.

\section{d. Strategi Weaknesess-Threats (WT)}

Strategi Strenghts-Threats Threats yang diperoleh dari faktor kelemahan internal dan ancaman eksternal yaitu meningkatkan kualitas sumber daya manusia dan pola manajemen agar 
terhindar dari cuaca buruk, produk yang cepat rusak dan serangan hama dan penyakit sehingga produktifitas bisa meningkat serta menerapkan teknik budidaya yang sesuai anjuran agar jagungyang dihasilkan bisa bersaing dengan produk sejenis dari luar dan bekerja sama dengan pedagang agar tidak terjadi fluktuasi harga dan petani bisa memperoleh ke ntngan lebih untuk dijadikan modal usaha nantinya.

\section{Pengambilan Keputusan}

Berdasarkan hasil anaisis SWOT alternatif strategi utama yang digunakan dalam pengembangan tanaman jagung berbasis agibisnis di Desa Pattondonsalu Kecamatan Maiwa Kabupaten Enrekang yaitu menggunakan Strategi Strenghts-Oppottunities yang diperoleh dari faktor kekuatan internal dan peluang eksternal yaitu Memanfaatkan ketersediaan lahan usaha tani untuk melakukan kegiatan budidaya jagung sehingga jumlah permintaan jagung dapat terpenuhi dengan pemanfaatan teknologi dan ketersediaan sarana produksi yang unggul dan bekualitas dengan bekerja sama dengan lembaga pendukung dan pengecer saprodi untuk memenuhi kebutuhan usaha tani dan bekerja sama dengan anggota kelompok tani untuk meningkatkan motifasi petani dan penyerapan tenaga kerja yang berasal dari kelompok tani sehingga dapat diperoleh keuntungan maksimal. Jika diakitkan dengan konsep agribisnis maka kegiatan usaha tani yang dikelolah secara bisnis untuk mendapatkan keuntungan melalui kerja sama yang adil sehingga dapat diperoleh produk pertanian yang bernilai tinggi dan berkelanjutan. Sejalan dengan penelitian (Taufik, 2013), mengemukakan strategi pengembangan untuk menciptakan produk yang berkualitas dan bernilai tambah serta meningkatkan pendapatan dan kesejahteraan petani yaitu dengan memaksimalkan potensi/kekuatan untuk meraih peluang dengan memanafatkan teknologi produksi, pangsa pasar, dukungan kebijakan pemerintah, penguatan lembaga pertanian dan peningkatan kualitas sumberdaya manusia (SDM).

\section{SIMPULAN DAN SARAN}

\section{Simpulan}

Berdasarkan hasil penelitian yang dilakukan diperoleh hasil identifikasi faktor internal kekuatan yaitu tersedianya lahan usaha tani, penggunaan bibit unggul, ketersediaan sarana produksi, bergabung kelompok tani, tingginya motifasi petani dan faktor internal kelemahan manajemen usaha tani, sumber daya manusia (SDM), belum menerapkan teknologi yang di anjurkan dan terbatasnya modal. Adapun hasil identifikasi faktor eksternal peluang yaitu permintaan jagung tinggi, pemanfaatan teknologi pertanian, adanya lembaga pendukung, penyerapan tenaga kerja, adanya pengecer saprodi dan faktor eksternal ancaman yaitu serangan hama dan penyakit, persaingan produk sejenis, perubahan cuaca, harga jagung fluktuasi dan produk mudah rusak.

Adapun hasil yang diperoleh berdasarkan hasil analisis dari perumusan alternatif strategi pengembangan tanaman jagung berbasis agribisnis yang diperoleh dari strategi SO yaitu Memanfaatkan ketersediaan lahan usaha tani untuk melakukan kegiatan budidaya jagung sehingga jumlah permintaan jagung dapat terpenuhi dengan pemanfaatan teknologi dan ketersediaan sarana produksi yang unggul dan bekualitas dengan bekerja sama dengan lembaga pendukung dan pengecer saprodi untuk memenuhi kebutuhan usaha tani dan bekerja sama dengan anggota kelompok tani untuk meningkatkan motifasi petani dan penyerapan tenaga kerja yang berasal dari kelompok tani sehingga dapat diperoleh keuntungan maksimal. 


\section{Saran}

Peneliti menyarankan kepada pihak yang terkait dalam penelitian ini sebagai berikut :

1. Bagi pemerintah perlu agar memfasilitasi kerjasama petani dengan lembaga-lembaga tataniaga jagung, guna mendukung program swasembada jagung sehingga dapat memudahkan petani mengakses pasar dalam pemasaran hasil jagung dan petani jagung akan sejahtera dengan penetapan kestabilan harga jagung

2. Bagi petani sebaiknya lebih memanfaatkan fungsi dan peran kelompok tani sebagai wadah dan pemberdayaan petani untuk mempermudah memperoleh informasi, berkomunikasi, akses pasar dan pengembangan teknologi.

3. Bagi peneliti selanjutnya sebaiknya meneliti tentang pengaruh lembaga penunjang terhadap usaha tani jagung sebagai pelengkap atas kelemahan yang berperan penting pada kegiatan usaha tani di desa Pattondonsalu.

\section{DAFTAR RUJUKAN}

Akbar, H. (2013). ANALISIS FAKTOR-FAKTOR YANG MEMPENGARUHI PRODUKSI JAGUNG. Program Study Agribisnis Fakultas Pertanian Universitas Muhammadiyah Sumatra Utara. Agrium, 18(1), 79-87.

Anwar \& Muhammad. (2019). Strategi Pengembangan Usahatani Jagung (Zea Mays L.) Di Kecamatan Aikmel Kabupaten Lombok Timur. Journal Ilmiah Rinjani, 7(2), 218-227.

Darwis, V. (2019). Potensi Kehilangan Hasil Panen Dan Pasca Panen Jagung Di Kabupaten Lampung Selatan. Journal of Food System \& Agribusiness, 2(1), 55-66. https://doi.org/10.25181/jofsa.v2i1.1110

Hasan, H., Laapo, A., \& Rauf, R. (2020). USAHATANI JAGUNG HIBRIDA DI KECAMATAN LABUAN KABUPATEN DONGGALA " Analysis of Income and Development Strategy of Hybrid Corn Farming at Labuan Sub District of Donggala Regency. Journal Agroland, 23(April 2016), 26-39.

Jufri, T. I. (2016). Strategi_Peningkatan_Produksi_Jagung_Dan. Program, Alumni Agribisnis, Studi Pertanian, Fakultas Sumatera, Universitas Pengajar, Staf Studi, Program Fakultas, Agribisnis Universitas, Pertanian Utara, Sumatera. Media Neliti, 9(2).

Lestari, Tri ND, Kusnandar, S. N. (2015). ANALISIS NILAI TAMBAH DAN STRATEGI PEMASARAN TORTILLA CHIPS JAGUNG DI HOME INDUSTRY INSAN MANDIRI KLATEN. J Pertan UNS, $9(1), 1-10$.

Nurdin, R., Yusriadi, Y., \& Sriwahyuningsih, A. E. (2021). Pengaruh Penggunaan Alsintan Terhadap Pendapatan Petani (Studi Kasus di Kelompok Tani Barantas Kab. Sidenreng Rappang). LaGeografia, 19(3), 273-283.

Rangkuti, F. (2017). ANALISIS SWOT. TEKNIK MEMBEDAH KASUS BISNIS. Jakarta. Gramedia Pustaka Utama.

Sari, I. N., Winandi, R., \& Agribisnis, D. (2012). Analisis Efisiensi Pemasaran Jagung Di Provinsi Nusa Tenggara Barat. Forum Agribisnis : Agribusiness Forum, 2(2), 191-210. https://doi.org/10.29244/fagb.2.2.191-210

Sugiyono. (2017). Metode penelitian Kualitatif, kuantitatif, dan R \& D. In Bandung: Alfabeta, $C V$. (Issue $\mathrm{X}$ ).

Taufik, M. (2013). Strategi Pengembangan Agribisnis Sayuran di Sulawesi Selatan. Jurnal Penelitian Dan Pengembangan Pertanian, 31(2), 30901. https://doi.org/10.21082/jp3.v31n2.2012.p\%p 